\title{
Growth and Yield Performance of Inbred and Hybrid Rice Varieties as Influenced by Combined Application of Organic and Inorganic Fertilizers
}

\author{
Raynilda R. Baoy ${ }^{1}$ and Dionesio M. Bañoc ${ }^{2}$ \\ ${ }^{I}$ Cebu Technological University, Argao, Cebu \\ ${ }^{2}$ Department of Agronomy, Visayas State University, \\ Visca, Baybay City, Leyte
}

\section{ABSTRACT}

The study evaluated the effects of organic and inorganic fertilizers on the growth and yield of two lowland rice varieties; determined the proper fertilizer combination; and evaluated the profitability of rice production as influenced by the combined application of organic and inorganic fertilizers. This was laid out in split plot arranged in a RCBD design with variety and fertilizer treatments as the main plot and subplot, respectively.

Results revealed that the period from sowing to heading, shoot dry weight, number of filled grains per panicle and weight of 1,000 grains were significantly influenced by the variety. The yield, yield components and harvest index (HI) were significantly influenced by fertilizer application. A significant interaction effect was noted on the period from sowing to heading as observed that inbred rice (NSIC Rc212) headed late than hybrid (TH82). Plants applied with 120-60-60 kg ha ${ }^{-1} \mathrm{~N}, \mathrm{P}_{2} \mathrm{O}_{5}$ and $\mathrm{K}_{2} \mathrm{O}$ produced taller height, larger LAI, longer panicles, more productive tillers and filled grains, and consequently highest grain yield and HI. These plants also produced the heaviest root and shoot dry weights resulting to higher root shoot ratio compared to unfertilized plants. Highest net income was obtained in plants applied with inorganic fertilizer at the rate of 120-60-60 $\mathrm{kg} \mathrm{ha}^{-1} \mathrm{~N}, \mathrm{P}_{2} \mathrm{O}_{5}, \mathrm{~K}_{2} \mathrm{O}$ due to high grain yield. Irrespective of fertilizer treatments, inbred rice was more profitable than hybrid. Highest production cost was incurred in plants applied with pure organic fertilizer due to the high cost of the material.

Keywords: Hybrid rice, Inbred rice, Inorganic Fertilizer, Organic fertilizer

\section{INTRODUCTION}

Rice (Oryza sativa L.) is an important food crop for a large proportion of the world's population and ranks second among the most cultivated cereals worldwide. It is a staple food of the majority of Filipinos and provides $35-60 \%$ of the calories consumed by more than 3 billion people

Correspondence: D.M. Bañoc , Address: Department of Agronomy, Visayas State University, Visca, Baybay City, Leyte, Philippines Email: dionesio.banoc@vsu.edu.ph

DOI: 10.32945/atr3915.2017 
around the world (FAO 2003). Generally, the increasing population aggravated by the negative impacts of climate change put pressure to rice farmers and all rice stakeholders to sustain the increase in rice production. It has been estimated that by the year 2025 it will be necessary to produce about $60 \%$ more rice than what is currently produced to meet the needs of a growing population (Fageria 2003).

Planting of certified high yielding inbred and hybrid rice varieties which can withstand adverse climatic changes is one of the best strategies to increasing rice yield. Hybrid rice has now been introduced throughout the rice growing regions to improve production and to attain rice selfsufficiency.

In the Philippines, available land for rice production is decreasing steadily due to urbanization and land degradation. Thus, there is a need to increase rice production through appropriate rice production practices in order to improve rice productivity or yield per unit area.

Among the production practices that need attention is the application of fertilizers. Fertilizer application is considered as the most common and conventional cultural management practices in overcoming the limitations of infertile soil and to obtain adequate supply of nutrients for better plant growth and development (Zamora 2007). Fertilizers are either organic or inorganic in form. Inorganic fertilizers are used in modern agriculture to correct plant nutrient deficiencies through provision of high levels of nutrients. However, their high cost makes them unaffordable to most farmers and they also cause negative impact on the nutrient budget of the soil. Furthermore, continuous application of synthetic fertilizers leads to soil degradation and loss of soil beneficial microorganisms which affects directly and indirectly our environment (Mohammad 2010).

The use of organic fertilizers to meet the nutrient requirement of crops is a popular alternative to the use of inorganic fertilizers. However, the use of organic manures alone may not be enough to satisfy the nutrient requirements of rice especially for the high yielding cultivars. An integrated nutrient management in which both organic manures and inorganic fertilizers are combined could be one of the methods of maintaining a healthy and sustainable soil system while increasing crop productivity (Palm et al 1997).

Varieties perform differently to the combined application of organic and inorganic fertilizers. Thus, this study was conducted to find out the most appropriate and economical fertilizer combination to attain higher yield of both inbred and hybrid rice varieties. Specifically, it aimed to: (1) evaluate the effects of OF Plus organic fertilizer applied singly or in combination with inorganic fertilizer on the growth and yield performance of inbred and hybrid lowland rice varieties; (2) determine the fertilizer combination that could provide optimum growth and yield performance of inbred and hybrid lowland rice varieties; and (3) evaluate the cost and return of inbred and hybrid lowland rice production with combined application of organic and inorganic fertilizers. 


\section{MATERIALS AND METHODS}

\section{Land Preparation}

A lowland area of 510 square meters was used for this study. This was plowed and harrowed twice at weekly interval to puddle the soil and to hasten the decomposition of weeds and rice stubbles as well as provide desirable tilth for better growth and development of the rice crop. Dikes around each treatment plot were constructed to avoid contaminations of applied fertilizers.

\section{Soil Sampling and Analysis}

Before transplanting, ten (10) soil samples were randomly collected from the experimental area at $0-30 \mathrm{~cm}$ depth using a soil auger. The soil samples were composited, air dried, pulverized and sieved using $2 \mathrm{~mm}$ wire mesh. They were then submitted to the Central Analytical Services Laboratory (CASL), PhilRootcrops, Visayas State University, Visca, Baybay City, Leyte for the analysis of soil $\mathrm{pH}$ and contents of organic matter, total $\mathrm{N}$, extractable $\mathrm{P}$ and exchangeable K. For the final soil analysis, composite soil samples were collected from each treatment plot right after harvest. These were analyzed at CASL for the same soil parameters mentioned above.

\section{Experimental Design and Field Layout}

The experiment was laid out in split plot arranged in a Randomized Complete Block Design (RCBD) with three replications. Rice varieties were assigned as the main plot and the different fertilizer applications as the subplot. Each replication was divided into ten (10) plots each measuring 2 $\mathrm{x} 5$ meters ( 10 square meters) with a total of 250 hills per plot. Alleyways of $1.0 \mathrm{~m}$ and $0.5 \mathrm{~m}$ between replications and treatment plots, respectively, were provided to facilitate farm management and data gathering. Irrigation and drainage canals were also constructed to facilitate water management and other farm operations. The different treatments were designated as follows:

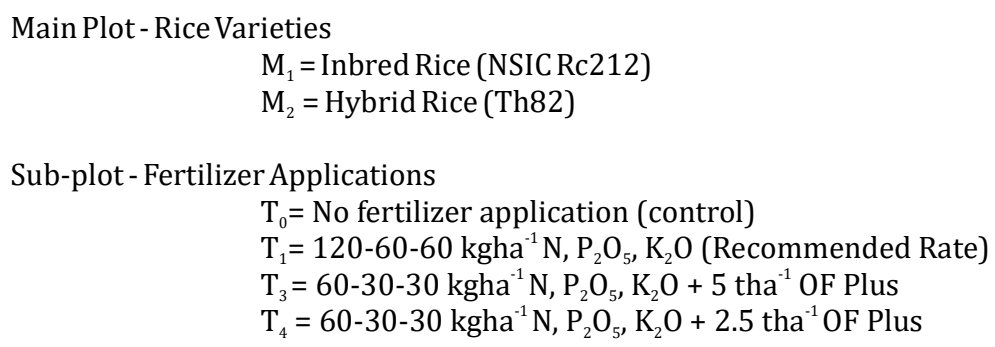


Collection, Preparation and Analysis of OF Plus Organic Fertilizer

OF Plus Organic Fertilizer was bought from Juanito Eco-Farm located at Brgy. Montebillo, Kananga, Leyte. A sample of the material was analyzed for $\mathrm{pH}$ and contents of organic matter, total $\mathrm{N}$, extractable $\mathrm{P}$ and exchangeable $\mathrm{K}$ at the Central Analytical Services Laboratory (CASL), PhilRootcrops, Visayas State University, Visca, Baybay City, Leyte.

Seedbed and Seedling Preparation

Seeds of inbred (NSIC Rc212) and hybrid (TH82) lowland rice varieties were soaked in water for 24 hours and 16 hours and incubated for 36 and 48 hours, respectively, before sowing in the seedbed. The pre-germinated seeds were uniformly distributed in the seedbed measuring $1 \mathrm{~m} \times 1 \mathrm{~m}$. complete fertilizer (14-14-14) at the rate of 15 grams per square meter was applied to the seedbed before sowing. To protect the seedbed from birds and other pests, seedbeds were covered with nets. Care and management were provided to the seedlings until they were ready for transplanting at 20 days after sowing.

Fertilizer and Fertilizer Application

The OF Plus organic fertilizer was incorporated into the soil two days before transplanting of seedlings. This was done by applying the fertilizer evenly into the soil and incorporating it by hand.

Urea (46-0-0) and complete fertilizer (14-14-14) were used to satisfy the recommended rate of $120-60-60 \mathrm{~kg} \mathrm{ha}^{-1}$ of $\mathrm{N}, \mathrm{P}_{2} \mathrm{O}_{5}$ and $\mathrm{K}_{2} \mathrm{O}$. Nitrogen was applied in three split applications at eight (8) days after transplanting, before panicle initiation (55 DAT) and at heading while all of the P and K were applied eight (8) days after transplanting. The actual amount of organic and inorganic fertilizers that were applied is reflected in Table 1.

Table 1. Actual amount of organic and inorganic fertilizers applied per plot

\begin{tabular}{|c|c|c|c|c|}
\hline \multirow{4}{*}{ Treatments } & \multicolumn{4}{|c|}{ Fertilizer Applied (kg) } \\
\hline & \multicolumn{2}{|c|}{ Basal } & \multicolumn{2}{|c|}{ Topdress } \\
\hline & \multirow[t]{2}{*}{$\begin{array}{l}\text { Complete } \\
(14-14-14) \\
\end{array}$} & \multirow[t]{2}{*}{ OF Plus } & \multicolumn{2}{|c|}{ Urea (46-0-0) } \\
\hline & & & P.I. (55 DAT) & Heading \\
\hline To- No fertilizer application & - & - & - & - \\
\hline $\begin{array}{c}\mathrm{T}_{1}-120-60-60 \mathrm{~kg} \mathrm{ha}^{-1} \mathrm{~N}, \mathrm{P}_{2} \mathrm{O}_{5} \\
\mathrm{~K}_{2} \mathrm{O} \text { inorganic fertilizer }\end{array}$ & 0.428 & - & 0.0652 & 0.0652 \\
\hline $\mathrm{T}_{2}-10$ tons ha ${ }^{-1}$ OF Plus & - & 10.00 & - & - \\
\hline $\mathrm{T}_{3}-5$ tons ha-1 OF Plus + 60-30- & & & & \\
\hline 30- kg ha-1 $\mathrm{N}, \mathrm{P}_{2} \mathrm{O}_{5}, \mathrm{~K}_{2} \mathrm{O}$ & 0.214 & 5.00 & 0.0326 & 0.0326 \\
\hline $\mathrm{T}_{4^{-}}-2.5$ tons ha ${ }^{-1}$ OF Plus $+60-$ & & & & \\
\hline 30- $30 \mathrm{~kg} \mathrm{ha}^{-1} \mathrm{~N}, \mathrm{P}_{2} \mathrm{O}_{5}, \mathrm{~K}_{2} \mathrm{O}$ & 0.214 & 2.50 & 0.0326 & 0.0326 \\
\hline
\end{tabular}


Transplanting

Twenty (20) day old seedlings were transplanted at the rate of one (1) seedling per hill at a spacing of $20 \mathrm{~cm} \times 20 \mathrm{~cm}$. Each treatment plot contained ten (10) rows and 25 hills or a total of 250 hills. Replanting of missing hills was done five (5) days after transplanting.

Weed Control

Rotary weeding was done at 14 days after transplanting (DAT) and this was followed by hand weeding one week later. Spot weeding was done to completely control weeds around each hill.

Water Management

Five (5) days after transplanting, the area was irrigated $3 \mathrm{~cm}$ deep water which was then raised gradually to five (5) $\mathrm{cm}$ depending on the growth of the transplanted seedlings. Water was reduced to $2.0 \mathrm{~cm}$ deep during the weeding operations and fertilizer application. During panicle initiation until flowering, water was maintained at a depth of five (5) to seven (7) $\mathrm{cm}$ and was drained two weeks before harvesting.

Control of Insect Pests and Diseases

Integrated pest management in combination with organic-based pesticides was employed to control insect pests and diseases throughout the growing period of the crop. Black bugs were controlled by spraying panyawan at $500 \mathrm{ml}$ per 16 liters water while rice bugs were controlled by spraying Lannate insecticide twice at $50 \mathrm{~g}$ pack for every 16 liters of water.

Harvesting

Rice plants within the harvestable area were harvested when approximately $85 \%$ of the grains in each plot had ripened as indicated by yellow color, firm and hard grains. The panicles were cut at the base of the plant using a sharp sickle. All the panicles in the six middle rows excluding one end hill in each row were threshed, cleaned and sundried to approximately $14 \%$ moisture content.

Data Gathered

\section{A. Agronomic Characteristics}

1. Days from sowing to heading - number of days from sowing up to the time when $50 \%$ of the panicles from each treatment plot had exerted from the flagleaf sheath. 
2. Days from sowing to maturity - days from sowing up to the time when $85 \%$ of the panicles in each treatment plot reached maturity.

3. Plant height $(\mathrm{cm})$ at heading - this was measured from ten (10) sample plants in each plot from the ground level up to the tip of the tallest part of the plant at heading stage.

4. Leaf area index (LAI) - the length and width of all the leaves from the middle tiller of five sample hills in each treatment plot (Gomez 1972). The length and width of each leaf was multiplied and the product was multiplied by the correction factor of 0.75 (Yoshida 1981). The mean was then multiplied by the total number of tillers per hill. The total leaf area of the five sample hills was divided by the ground area occupied as shown in the formula:

$$
\mathrm{LAI}=\frac{\text { Total Leaf Area (5 hills) }}{\text { Ground Area Covered by } 5 \text { hills }(2,000 \mathrm{~cm} 2)}
$$

where:

$$
\begin{gathered}
\text { Leaf Area = Length } \times \text { Width } \times C F(0.75) \\
\text { Total leaf area } \text { hill }^{-1}=\text { Mean leaf area of the middle tiller } \mathrm{x} \text { total } \\
\text { number of tillers }
\end{gathered}
$$

5. Fresh straw yield $\left(\mathrm{t} \mathrm{ha}^{-1}\right)$ - all plants in the six (6) inner rows in each plot excluding the four border rows and end plants of each row were cut from the ground level and weighed. The plot yields were converted into tons per hectare basis using the formula:

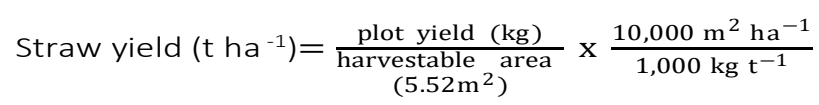

6. Number of nodal roots per plant - all the nodal roots (adventitious roots that form rings from stem tissues around a node) which emanated from each of the three sample plants per treatment plot were counted. Destructive sampling was done from plants taken from the $2^{\text {nd }}$ and the 9 th rows at heading stage.

7. Nodal root axis length per plant $(\mathrm{cm})$ - length from the base to the tip of each of the nodal roots of the three sample plants per treatment plot.

8. Root dry weight per plant (g) - weight of the oven dried roots of the three sample plants after cleaning the root samples at heading stage. The said samples were oven dried at $70^{\circ} \mathrm{C}$ for 72 hours before weighing.

9. Shoot dry weight per plant (g) - weight of the oven dried shoots of the three sample plants at heading stage. The said samples were oven dried at $70^{\circ} \mathrm{C}$ for 72 hours before weighing. 
10. Root shoot ratio per plant - root dry weight divided by the shoot dry weight of the three sample plants per treatment plot.

\section{B. Yield and Yield Components}

1. Number of productive tillers per hill - number of tillers that develop panicles from ten (10) sample plants in each treatment plot at maturity.

2. Number of filled and unfilled grains per panicle - number of filled and unfilled grains of ten (10) sample panicles in each treatment plot.

3. Percentage of filled grains - number of filled grains divided by the total number of grains in each panicle.

4. Panicle length $(\mathrm{cm})$ - length of the ten (10) sample panicles in each treatment plot.

5. Weight of 1,000 grains (g) - weight of 1,000 grains obtained randomly from each treatment plot. Prior to weighing, the grains were cleaned, sun dried to $14 \%$ moisture content.

6. Grain yield $\left(\mathrm{t} \mathrm{ha}^{-1}\right)$ - this is the weight of the total grains harvested within the harvestable area in each treatment plot. The grains were cleaned, sundried and weighed. The weight of grains per plot at 14 $\%$ moisture content was converted into tons per hectare using the formula:

$$
\text { Grain yield } \mathrm{t} \mathrm{ha}^{-1}=\frac{\text { Plot yield } \mathrm{kg}}{\text { harvestable area (5.52 sq m) }} \times \frac{10,000 \mathrm{~m}^{2} \mathrm{ha}^{-1}}{1,000 \mathrm{~kg} \mathrm{t}^{-1}}
$$

C. Harvest Index (HI) - this is the ratio of econonfic field to biological yield and this was obtained by dividing the grain weight by the total dry matter at harvest. This was done by harvesting at random three (3) sample hills from each treatment plot. Harvest index was computed using the formula:

$$
\mathrm{HI}=\frac{\text { Economic yield }}{\text { Biological yield }}=\frac{\text { dry grain weight }(\mathrm{g})}{\text { dry straw weight } \mathrm{g}+\text { dry grain weight } \mathrm{g}+\text { chaff }}
$$

\section{Production Cost and Return Analysis}

Production cost was determined by recording all the expenses incurred throughout the conduct of the study from land preparation, harvesting and postharvest handling operations. Gross income was computed by multiplying the grain yield of each treatment plot to the current price of dried palay. Net profit was obtained by subtracting the total expenses from the gross income using the formula: 


\section{E. Meteorological Data}

Data on total weekly rainfall $(\mathrm{mm})$, average daily minimum and maximum temperatures $\left({ }^{\circ} \mathrm{C}\right)$ and relative humidity $(\%)$ throughout the conduct of the study were obtained from the Philippine Atmospheric Geophysical and Astronomical Services Administration (PAGASA) Station, Visayas State University, Visca, Baybay City, Leyte, Philippines.

\section{F. Statistical Tool}

All data gathered were analyzed using the Statistical Tool for Agricultural Research (STAR) for the analysis of variance (ANOVA) while the comparison of treatment means were subjected to Tukey's Studentized Range (HSD) test.

\section{RESULTS AND DISCUSSION}

\section{Soil Analysis}

Analysis of the soil samples before crop establishment showed that the soil had a $\mathrm{pH}$ of $5.11,5.46 \%$ organic matter (OM) (2.73 \% organic carbon), $0.297 \%$ total N, $13.62 \mathrm{mg} \mathrm{kg}^{-1}$ available phosphorous (P) and $1.39 \mathrm{me} 100 \mathrm{~g}$ ${ }^{1}$ exchangeable potassium (K). The result implies that the soil was strongly acidic, low in organic matter (OM), medium amount of $\mathrm{N}$ and high amounts of available $\mathrm{P}$ and exchangeable $\mathrm{K}$ (Landon 1991).

Table 2. Chemical properties of the soil before planting (initial analysis) and after harvesting (final analysis) of lowland rice (Oryza sativa L.) as influenced by different varieties and combined application of organic and inorganic fertilizers

\begin{tabular}{|c|c|c|c|c|c|}
\hline Treatment & $\mathrm{pH}$ & $\mathrm{OM}(\%)$ & Total N (\%) & $\begin{array}{c}\text { Available P } \\
\left(\mathrm{mg} \mathrm{kg}^{-1}\right)\end{array}$ & $\begin{array}{c}\text { Exchangeable K } \\
\quad\left({\left.\text { me } 100 \mathrm{~g}^{-1}\right)}^{-1}\right.\end{array}$ \\
\hline \multicolumn{6}{|c|}{ Initial analysis } \\
\hline & 5.11 & 5.46 & 0.297 & 13.62 & 1.39 \\
\hline \multirow{2}{*}{\multicolumn{6}{|c|}{$\begin{array}{c}\underline{\text { Final analysis }} \\
\text { Hybrid Rice (TH82) }\end{array}$}} \\
\hline & & & & & \\
\hline & 5.36 & 3.29 & 0.18 & 9.78 & 0.45 \\
\hline \multicolumn{6}{|c|}{ Inbred Rice (NSIC Rc212) } \\
\hline & 5.23 & 3.89 & 0.19 & 10.69 & 0.46 \\
\hline
\end{tabular}

Result of the final soil analysis revealed that the soil $\mathrm{pH}$ increased from 5.11 to 5.23 for inbred plots and 5.36 in hybrid plots due to the application of organic and inorganic fertilizers while there was a reduction in the amounts of $\mathrm{OM}$, total $\mathrm{N}$, available $\mathrm{P}$ and exchangeable $\mathrm{K}$. The decrease 
in the amounts of $\mathrm{OM}$, total $\mathrm{N}$, available $\mathrm{P}$ and exchangeable $\mathrm{K}$ might be attributed to the utilization of nutrients by the crops and losses due to leaching and run-off during irrigation and drainage.

On the other hand, OF Plus organic fertilizer plots had a $\mathrm{pH}$ of 8.47, $14.82 \% \mathrm{OM}, 1.48 \%$ total $\mathrm{N}, 5.67 \mathrm{mg} \mathrm{kg}^{-1}$ available $\mathrm{P}, 0.307 \mathrm{me} 100 \mathrm{~g}^{-1}$ exchangeable Kand $1.48 \mathrm{mg} \mathrm{kg}^{-1}$ arsenic.

Agronomic Characteristics

Table 3 shows the agronomic characteristics of lowland rice as influenced by variety and combined application of organic and inorganic fertilizers. Results revealed that only the number of days from sowing to heading was significantly influenced by the variety used and not by the application of organic and inorganic fertilizers. All other agronomic parameters were significantly influenced by the application of fertilizers either applied singly or combined (Table 3). A significant interaction effect between rice variety and the combined application of organic and inorganic fertilizers was noted on the number of days from sowing to heading. Hybrid lowland rice (TH82) significantly headed earlier than inbred rice (NSIC Rc212) but their maturity did not vary significantly. However, their maturity, height, leaf area index and fresh straw yield were affected by the combined application of organic and inorganic fertilizers. Rice plants applied with $120-60-60 \mathrm{~kg} \mathrm{ha}^{-1} \mathrm{~N}, \mathrm{P}_{2} \mathrm{O}_{5}, \mathrm{~K}_{2} \mathrm{O}$ pure inorganic fertilizer significantly grew tallest with largest LAI and consequently heaviest straw yield. On the other hand, plants applied with 2.5 and $5 \mathrm{t} \mathrm{ha}^{-1}$ OF Plus organic fertilizer combined with 60-30-30 $\mathrm{kg} \mathrm{ha}^{-1} \mathrm{~N}, \mathrm{P}_{2} \mathrm{O}_{5}, \mathrm{~K}_{2} \mathrm{O}$ inorganic fertilizers $\left(\mathrm{T}_{3}\right.$ and $\left.\mathrm{T}_{4}\right)$ had comparable height and LAI. Those plants applied with pure organic $\left(\mathrm{T}_{2}\right)$ were comparable to the unfertilized ones $\left(\mathrm{T}_{0}\right)$. The taller plants and larger LAI obtained with application of 120 60-60 kg ha ${ }^{-1} \mathrm{~N}, \mathrm{P}_{2} \mathrm{O}_{5}, \mathrm{~K}_{2} \mathrm{O}$ could be due to the readily available supply of macro nutrients needed by crops for their growth and development. This study corroborates the findings of Patolilic (1988) that increasing the rate of nitrogen from 30 to $60 \mathrm{~kg} \mathrm{ha}^{-1}$ significantly increased the leaf area index of rice. This also conforms to the findings of earlier studies that longer and wider leaves are usually manifested in taller plants resulting in higher LAI than in shorter plants (Chang \& Vergara 1972). 
Table 3. Agronomic characteristics of lowland rice (Oryza sativa L.) as influenced by different varieties and combined application of organic and inorganic fertilizers

\begin{tabular}{|c|c|c|c|c|c|}
\hline \multirow{2}{*}{ Treatment } & \multicolumn{2}{|c|}{ Days from sowing to } & \multirow{2}{*}{$\begin{array}{l}\text { Plant } \\
\text { Height } \\
(\mathrm{cm})\end{array}$} & \multirow{2}{*}{$\begin{array}{l}\text { Leaf Area } \\
\text { Index }\end{array}$} & \multirow{2}{*}{$\begin{array}{c}\text { Fresh } \\
\text { straw } \\
\text { yield } \\
\left(\mathrm{t} \mathrm{ha}^{-1}\right)\end{array}$} \\
\hline & Heading & Maturity & & & \\
\hline \multicolumn{6}{|l|}{$\underline{\text { Varieties }}$} \\
\hline Hybrid (TH82) & $67.47 b$ & 111.47 & 108.33 & 6.11 & 19.09 \\
\hline Inbred (NSIC Rc212) & $69.20 \mathrm{a}$ & 111.87 & 105.80 & 5.61 & 19.41 \\
\hline \multicolumn{6}{|l|}{ Fertilizer Application } \\
\hline $\mathrm{T}_{0}$-No fertilizer application (control) & 68.50 & $109.67 \mathrm{c}$ & $99.00 \mathrm{c}$ & $3.59 \mathrm{~d}$ & $14.01 \mathrm{~d}$ \\
\hline $\mathrm{T}_{1}-120-60-60 \mathrm{~kg} \mathrm{ha}^{-1} \mathrm{~N}, \mathrm{P}_{2} \mathrm{O}_{5}, \mathrm{~K}_{2} \mathrm{O}$ & 68.83 & $113.83 \mathrm{a}$ & 114.67 a & $8.02 \mathrm{a}$ & $24.43 a$ \\
\hline $\mathrm{T}_{2}-10 \mathrm{t} \mathrm{ha}^{-1}$ OF Plus & 69.00 & $111.67 \mathrm{~b}$ & $102.33 \mathrm{c}$ & $4.79 \mathrm{~cd}$ & $16.80 \mathrm{c}$ \\
\hline $\begin{array}{l}\mathrm{T}_{3}-60-30-30 \mathrm{~kg} \mathrm{ha}^{-1} \mathrm{~N}, \mathrm{P}_{2} \mathrm{O}_{5}, \mathrm{~K}_{2} \mathrm{O}+5 \mathrm{t} \\
\text { ha-1 }^{-1} \text { OF Plus }\end{array}$ & 69.17 & $112.33 \mathrm{ab}$ & $109.00 \mathrm{~b}$ & $6.99 a b$ & $21.47 b$ \\
\hline $\begin{array}{l}\mathrm{T}_{4}-60-30-30 \mathrm{~kg} \mathrm{ha}^{-1} \mathrm{~N}, \mathrm{P}_{2} \mathrm{O}_{5}, \mathrm{~K}_{2} \mathrm{O}+2.5 \\
\mathrm{tha^{-1 }} \text { OF Plus }\end{array}$ & 67.84 & $111.67 \mathrm{~b}$ & $110.33 a b$ & 5.91 bc & $19.53 b$ \\
\hline C.V. a (\%) & 2.11 & 0.65 & 4.35 & 24.45 & 33.81 \\
\hline C.V. b (\%) & 1.18 & 0.82 & 2.74 & 15.26 & 13.61 \\
\hline
\end{tabular}

Means in a column with the same letter and no letter designation are not significantly different based on $5 \%$ level of significance in HSD

In terms of fresh straw yield, plants applied with $120-60-60 \mathrm{~kg} \mathrm{ha}^{-1} \mathrm{~N}$, $\mathrm{P}_{2} \mathrm{O}_{5}, \mathrm{~K}_{2} \mathrm{O}\left(\mathrm{T}_{1}\right)$ produced the heaviest straw yield of $24.43 \mathrm{t} \mathrm{ha}^{-1}$ followed by plants applied with 5 and $2.5 \mathrm{t} \mathrm{ha}^{-1}$ OF Plus combined with inorganic fertilizer at 60-30-30 $\mathrm{kg} \mathrm{ha}^{-1} \mathrm{~N}, \mathrm{P}_{2} \mathrm{O}_{5}, \mathrm{~K}_{2} \mathrm{O}$. Plants applied with organic fertilizer alone at 10 tha $^{-1}$ OF Plus produced straw yield of 16.80 tha $^{-1}$ which was higher than the straw yield (14.01 tha ${ }^{-1}$ ) obtained in unfertilized control $\left(\mathrm{T}_{0}\right)$.

A significant interaction effect between rice varieties and fertilizer treatments was observed on the number of days from sowing to heading (Table 4). Statistical analysis revealed that inbred rice (NSIC Rc212) headed late than hybrid lowland rice (TH82) when applied with $10 \mathrm{t} \mathrm{ha}^{-1}$ of OF Plus. On the other hand, hybrid plants without fertilizer application headed earlier than those which received combined application of 60-30$30 \mathrm{~kg} \mathrm{ha}^{-1} \mathrm{~N}, \mathrm{P}_{2} \mathrm{O}_{5}, \mathrm{~K}_{2} \mathrm{O}$ with 5 tha ${ }^{-1}$ OF Plus.

Table 4. Interaction effects on the number of days from sowing to heading of lowland rice (Oryza sativa L.) as influenced by the different varieties and combined application of organic and inorganic fertilizers

\begin{tabular}{|c|c|c|}
\hline Treatment & $\begin{array}{l}\text { Hybrid } \\
\text { (TH82) }\end{array}$ & $\begin{array}{c}\text { Inbred } \\
\text { (NSIC Rc212) }\end{array}$ \\
\hline $\mathrm{T}_{0^{-}}$No fertilizer application (control) & $65.67 \mathrm{~d}$ & $70.00 \mathrm{ab}$ \\
\hline $\mathrm{T}_{1}-120-60-60 \mathrm{~kg} \mathrm{ha}^{-1} \mathrm{~N}, \mathrm{P}_{2} \mathrm{O}_{5}, \mathrm{~K}_{2} \mathrm{O}$ & $68.00 \mathrm{bcd}$ & $69.00 \mathrm{ab}$ \\
\hline $\mathrm{T}_{2}-10 \mathrm{t} \mathrm{ha}^{-1}$ OF Plus & $66.33 \mathrm{~cd}$ & $71.33 \mathrm{a}$ \\
\hline $\begin{array}{l}\mathrm{T}_{3}-60-30-30 \mathrm{~kg} \mathrm{ha}^{-1} \mathrm{~N}_{,} \mathrm{P}_{2} \mathrm{O}_{5}, \mathrm{~K}_{2} \mathrm{O} \\
+5 \mathrm{tha}^{-1} \text { OF Plus }\end{array}$ & $68.33 b c$ & $69.67 \mathrm{ab}$ \\
\hline $\begin{array}{l}\mathrm{T}_{4}-60-30-30 \mathrm{~kg} \mathrm{ha}^{-1} \mathrm{~N}, \mathrm{P}_{2} \mathrm{O}_{5}, \mathrm{~K}_{2} \mathrm{O} \\
+2.5 \mathrm{t} \mathrm{ha}^{-1} \text { OF Plus }\end{array}$ & $68.00 \mathrm{bcd}$ & $70.33 a b$ \\
\hline
\end{tabular}

Means in a column and rows with the same letter and no letter designations are not significantly different based on $5 \%$ level of significance in HSD 
Table 5 presents the data on shoot dry weight and root parameters of lowland rice as influenced by variety and combined application of organic and inorganic fertilizers. Statistical analysis revealed that hybrid and inbred varieties differed only in shoot dry weight but not in all root parameters being studied. Hybrid lowland rice (TH82) significantly produced heavier shoot dry weight than inbred rice (NSIC Rc212). The result could be related to the development of slightly taller plants and broader leaves in hybrid rice (TH82) than inbred rice (NSIC Rc212) which could be an inherent characteristic of TH 82 hybrid rice variety.

Table 5. Shoot dry weight and root parameters of lowland rice (Oryza sativa L.) as influenced by different varieties and combined application of organic and inorganic fertilizers

\begin{tabular}{|c|c|c|c|c|c|}
\hline Treatment & $\begin{array}{c}\text { Shoot } \\
\text { Dry } \\
\text { Weight } \\
\text { per Plant } \\
\text { (g) }\end{array}$ & $\begin{array}{l}\text { No. of } \\
\text { Nodal } \\
\text { Roots per } \\
\text { Plant }\end{array}$ & $\begin{array}{c}\text { Nodal } \\
\text { Root Axis } \\
\text { Length } \\
\text { per Plant } \\
\text { (m) }\end{array}$ & $\begin{array}{l}\text { Root Dry } \\
\text { Weight } \\
\text { per Plant } \\
\text { (g) }\end{array}$ & $\begin{array}{c}\text { Root } \\
\text { Shoot } \\
\text { Ratio }\end{array}$ \\
\hline \multicolumn{6}{|l|}{ Varieties } \\
\hline 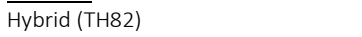 & $52.02 \mathrm{a}$ & 351.00 & 34.42 & 2.02 & 0.039 \\
\hline Inbred (NSIC Rc212) & $48.71 \mathrm{~b}$ & 334.70 & 34.37 & 1.95 & 0.040 \\
\hline \multicolumn{6}{|l|}{ Fertilizer Application } \\
\hline $\mathrm{T}_{0}$-No fertilizer application (control) & $42.94 \mathrm{c}$ & 306.67 & 31.99 & $1.29 \mathrm{e}$ & $0.03 \mathrm{c}$ \\
\hline $\mathrm{T}_{1}-120-60-60 \mathrm{~kg} \mathrm{ha}^{-1} \mathrm{~N}, \mathrm{P}_{2} \mathrm{O}_{5}, \mathrm{~K}_{2} \mathrm{O}$ & $57.61 \mathrm{a}$ & 354.17 & 38.19 & $2.88 \mathrm{a}$ & $0.05 a$ \\
\hline $\mathrm{T}_{2}-10 \mathrm{t} \mathrm{ha}^{-1}$ OF Plus & $48.61 \mathrm{~b}$ & 330.50 & 32.93 & $1.62 \mathrm{~d}$ & $0.03 \mathrm{bc}$ \\
\hline $\begin{array}{l}\mathrm{T}_{3}-60-30-30 \mathrm{~kg} \mathrm{ha}^{-1} \mathrm{~N}, \mathrm{P}_{2} \mathrm{O}_{5}, \mathrm{~K}_{2} \mathrm{O}+ \\
5 \mathrm{t} \mathrm{ha}^{-1} \text { OF Plus }\end{array}$ & $51.22 \mathrm{~b}$ & 334.17 & 33.75 & $2.41 \mathrm{~b}$ & $0.05 \mathrm{a}$ \\
\hline $\begin{array}{l}\mathrm{T}_{4}-60-30-30 \mathrm{~kg} \mathrm{ha}^{-1} \mathrm{~N}, \mathrm{P}_{2} \mathrm{O}_{5}, \mathrm{~K}_{2} \mathrm{O}+ \\
2.5 \mathrm{t} \mathrm{ha}^{-1} \text { OF Plus }\end{array}$ & $51.45 \mathrm{~b}$ & 348.00 & 35.04 & $1.98 \mathrm{c}$ & $0.04 \mathrm{~b}$ \\
\hline C.V.(a) \% & 2.53 & 10.31 & 24.27 & 9.19 & 8.90 \\
\hline C.V.(b) \% & 6.04 & 12.07 & 15.80 & 6.20 & 7.95 \\
\hline
\end{tabular}

Irrespective of fertilizer application treatments, plants produced more or less the same number of nodal roots and nodal root axis length. On the other hand, plants applied with 120-60-60 kg ha ${ }^{-1} \mathrm{~N}, \mathrm{P}_{2} \mathrm{O}_{5}, \mathrm{~K}_{2} \mathrm{O}$ significantly produced the heaviest shoot (57.61 g), root dry weight (2.88 g) and root shoot ratio (0.05). The root shoot ratio of plants applied with $60-30-30 \mathrm{~kg}$ ha ${ }^{-1} \mathrm{~N}, \mathrm{P}_{2} \mathrm{O}_{5}, \mathrm{~K}_{2} \mathrm{O}$ combined with 5 t ha ${ }^{-1} \mathrm{OF}$ Plus $\left(\mathrm{T}_{3}\right)$ was comparable to those applied with pure inorganic fertilizer at 120-60-60 kg ha ${ }^{-1} \mathrm{~N}, \mathrm{P}_{2} \mathrm{O}_{5}, \mathrm{~K}_{2} \mathrm{O}\left(\mathrm{T}_{1}\right)$. The limited root growth and development of the root system of unfertilized plants might be due to the decreased translocation of photosynthates to the roots (Bidwell, 1974). This result conformed with the findings of 0 Toole and Bland (1987) as cited by Bañoc (2000) that abundant number of nodal roots and the longer nodal root axis were strong manifestations of the ability of rice plants to alter its root physiology and morphology in response to the changing soil environment. 
The yield, yield components and harvest index of lowland rice are presented in Tables 6 and 7. Results revealed that the number of filled grains per panicle and the weight of 1,000 grains differed significantly between varieties tested. There were no significant differences observed on the number of productive tillers per hill, panicle length, $\%$ filled grains, grain yield and harvest index of the varieties evaluated.

With regard to the different fertilizer treatments, most of the yield and yield components and harvest index were significantly affected except the percent filled grains. There were no interaction effects between varieties and different fertilizer treatments in relation to the yield, yield components and harvest index.

Plants applied with inorganic fertilizer at $120-60-60 \mathrm{~kg} \mathrm{ha}^{-1} \mathrm{~N}, \mathrm{P}_{2} \mathrm{O}_{5}$, $\mathrm{K}_{2} \mathrm{O}$ produced significantly more productive tillers per hill (15.50) than those plants applied with pure organic at $10 \mathrm{t} \mathrm{ha}^{-1} \mathrm{OF}$ Plus and the unfertilized plants. Those which received 60-30-30 kg ha ${ }^{-1} \mathrm{~N}, \mathrm{P}_{2} \mathrm{O}_{5}, \mathrm{~K}_{2} \mathrm{O}+5 \mathrm{t}$ ha ${ }^{-1}$ OF Plus $\left(\mathrm{T}_{4}\right)$ and 60-30-30 kg ha- $\mathrm{N}^{-1} \mathrm{P}_{2} \mathrm{O}_{5}, \mathrm{~K}_{2} \mathrm{O}+2.5$ tha $^{-1}$ OF Plus $\left(\mathrm{T}_{3}\right)$ gave comparable productive tillers with those applied with $120-60-60 \mathrm{~kg} \mathrm{ha}^{-1} \mathrm{~N}$, $\mathrm{P}_{2} \mathrm{O}_{5}, \mathrm{~K}_{2} \mathrm{O}$. Those applied with pure OF Plus produced more or less the same productive tillers with those treated with combined 2.5 and 5 tha $^{-1}$ and 60 30-30 kg ha ${ }^{-1} \mathrm{~N}, \mathrm{P}_{2} \mathrm{O}_{5}, \mathrm{~K}_{2} \mathrm{O}$. The unfertilized plants as expected gave the lowest number of productive tillers (10.5). This result suggests that application of fertilizer particularly inorganic fertilizer promoted the growth and development of more productive tillers per hill. Panicle length exhibited the same trend with that of the number of productive tillers.

Table 6. Yield components of lowland rice (Oryza sativa L.) as influenced by different varieties and combined application of organic and inorganic fertilizers

\begin{tabular}{|c|c|c|c|c|}
\hline Treatment & $\begin{array}{c}\text { No. of } \\
\text { Productive } \\
\text { Tillers } \\
\text { per hill }\end{array}$ & $\begin{array}{l}\text { Length of } \\
\text { Panicle } \\
(\mathrm{cm})\end{array}$ & $\begin{array}{c}\text { No. of } \\
\text { Filled Grains } \\
\text { per panicle }\end{array}$ & $\begin{array}{c}\% \\
\text { Filled Grains }\end{array}$ \\
\hline \multicolumn{5}{|l|}{ Varieties } \\
\hline$\overline{\text { Hybrid (TH82) }}$ & 12.40 & 27.53 & $160.17 a$ & 68.32 \\
\hline Inbred (NSIC Rc212) & 14.67 & 26.28 & $84.33 b$ & 66.43 \\
\hline \multicolumn{5}{|l|}{ Fertilizer Application } \\
\hline $\mathrm{T}_{0}$-No fertilizer application (control) & $10.50 c$ & $24.72 c$ & $102.28 b$ & 69.67 \\
\hline $\mathrm{T}_{1}-120-60-60 \mathrm{~kg} \mathrm{ha}^{-1} \mathrm{~N}, \mathrm{P}_{2} \mathrm{O}_{5}, \mathrm{~K}_{2} \mathrm{O}$ & $15.50 \mathrm{a}$ & $28.06 a$ & $133.88 \mathrm{a}$ & 65.46 \\
\hline $\mathrm{T}_{2}-10$ t ha-1 $^{-1}$ OF Plus & $13.50 b$ & $26.46 b$ & $119.38 \mathrm{ab}$ & 68.42 \\
\hline $\begin{array}{l}\mathrm{T}_{3}-60-30-30 \mathrm{~kg} \mathrm{ha}^{-1} \mathrm{~N} \mathrm{P}_{2} \mathrm{O}_{5}, \mathrm{~K}_{2} \mathrm{O}+5 \mathrm{t} \\
\text { ha-1 OF Plus }\end{array}$ & $13.83 a b$ & $27.74 a b$ & $132.90 \mathrm{a}$ & 68.12 \\
\hline $\begin{array}{l}\mathrm{T}_{4}-60-30-30 \mathrm{~kg} \mathrm{ha}^{-1} \mathrm{~N}_{,} \mathrm{P}_{2} \mathrm{O}_{5}, \mathrm{~K}_{2} \mathrm{O}+2.5 \\
\text { tha- }{ }^{-1} \text { OF Plus }\end{array}$ & $14.33 \mathrm{ab}$ & $27.54 a b$ & $122.78 \mathrm{a}$ & 65.20 \\
\hline C.V.(a) & 13.69 & 3.03 & 14.41 & 11.14 \\
\hline C.V. (b) & 7.36 & 2.81 & 11.70 & 8.08 \\
\hline
\end{tabular}

Means in a column with the same letter and no letter designation are not significantly different based on $5 \%$ level of significance in HSD 
Likewise, a significant difference was also noted on the number of filled grains per panicle but not on the percentage of filled grains. Rice plants applied with $120-60-60 \mathrm{~kg} \mathrm{ha}^{-1} \mathrm{~N}, \mathrm{P}_{2} \mathrm{O}_{5}, \mathrm{~K}_{2} \mathrm{O}\left(\mathrm{T}_{1}\right)$ produced significantly more filled grains (133.88) than the unfertilized plants. However, plants applied with pure organic fertilizer at $10 \mathrm{t} \mathrm{ha}^{-1}$ and those applied with combined organic and inorganic fertilizers $\left(\mathrm{T}_{3}\right.$ and $\left.\mathrm{T}_{4}\right)$ gave comparable number of filled grains with those applied with 120-60-60 kg ha ${ }^{-1} \mathrm{~N}, \mathrm{P}_{2} \mathrm{O}_{5}, \mathrm{~K}_{2} \mathrm{O}\left(\mathrm{T}_{1}\right)$.

Moreover, the weight of 1,000 grains was significantly influenced by the different fertilizer treatments (Table 7). Plants applied with combined organic and inorganic fertilizers at the rate of $60-30-30 \mathrm{~kg} \mathrm{ha}^{-1} \mathrm{~N}$, $\mathrm{P}_{2} \mathrm{O}_{5}, \mathrm{~K}_{2} \mathrm{O}+5 \mathrm{t} \mathrm{ha}^{-1}$ OF Plus obtained the heaviest 1,000 grains with $25.25 \mathrm{~g}$ than the unfertilized plants $\left(\mathrm{T}_{0}\right)$. However, this was comparable to those plants applied with inorganic fertilizer at 120-60-60 $\mathrm{kg} \mathrm{ha}^{-1} \mathrm{~N}, \mathrm{P}_{2} \mathrm{O}_{5}, \mathrm{~K}_{2} \mathrm{O}\left(\mathrm{T}_{1}\right)$, those applied with 60-30-30 kg ha ${ }^{-1} \mathrm{~N}, \mathrm{P}_{2} \mathrm{O}_{5}, \mathrm{~K}_{2} \mathrm{O}+2.5$ tha $^{-1}$ OF Plus $\left(\mathrm{T}_{4}\right)$ and those with pure organic fertilizer ( 10 tha $^{-1} \mathrm{OF}$ Plus).

Table 7. Weight ( $\mathrm{g}$ ) of 1,000 grains, grain yield ( $\mathrm{t}$ ha ${ }^{-1}$ ) and harvest index of lowland rice (Oryza sativa L.) as influenced by different varieties and combined application of organic and inorganic fertilizers

\begin{tabular}{|c|c|c|c|}
\hline Treatment & $\begin{array}{l}\text { Weight of } \\
1,000 \\
\text { Grains (g) }\end{array}$ & $\begin{array}{l}\text { Grain } \\
\text { Yield } \\
\left(\text { t ha }^{-1}\right)\end{array}$ & $\begin{array}{l}\text { Harvest } \\
\text { Index }\end{array}$ \\
\hline \multicolumn{4}{|l|}{ Varieties } \\
\hline Hybrid (TH82) & $21.29 \mathrm{~b}$ & 4.90 & 0.40 \\
\hline Inbred (NSIC Rc212) & $28.25 \mathrm{a}$ & 4.91 & 0.40 \\
\hline \multicolumn{4}{|l|}{ Fertilizer Application } \\
\hline $\mathrm{T}_{0}$-No fertilizer application (control) & $24.40 \mathrm{~b}$ & $3.36 \mathrm{~d}$ & $0.39 \mathrm{c}$ \\
\hline $\mathrm{T}_{1}-120-60-60 \mathrm{~kg} \mathrm{ha}^{-1} \mathrm{~N}, \mathrm{P}_{2} \mathrm{O}_{5}, \mathrm{~K}_{2} \mathrm{O}$ & $24.85 a b$ & $5.98 \mathrm{a}$ & $0.42 \mathrm{a}$ \\
\hline $\mathrm{T}_{2}-10 \mathrm{t} \mathrm{ha}^{-1}$ OF Plus & $24.60 \mathrm{ab}$ & $4.32 \mathrm{c}$ & $0.38 \mathrm{c}$ \\
\hline $\mathrm{T}_{3}-60-30-30 \mathrm{~kg} \mathrm{ha}^{-1} \mathrm{~N}, \mathrm{P}_{2} \mathrm{O}_{5}, \mathrm{~K}_{2} \mathrm{O}+5 \mathrm{tha}^{-1}$ OF Plus & $25.25 \mathrm{a}$ & $5.55 a b$ & $0.41 b$ \\
\hline $\mathrm{T}_{4}-60-30-30 \mathrm{~kg} \mathrm{ha}^{-1} \mathrm{~N}, \mathrm{P}_{2} \mathrm{O}_{5}, \mathrm{~K}_{2} \mathrm{O}+2.5 \mathrm{t} \mathrm{ha}^{-1}$ OF Plus & $24.73 a b$ & $5.30 \mathrm{~b}$ & $0.39 c$ \\
\hline C.V.(a)\% & 3.96 & 1.18 & 2.00 \\
\hline C.V.(b)\% & 1.52 & 5.98 & 2.02 \\
\hline
\end{tabular}

Means in a column with the same letter and no letter designation are not significantly different based on $5 \%$ level of significance in HSD

Regarding grain yield, plants applied with inorganic fertilizer at the rate of 120-60-60 $\mathrm{kg} \mathrm{ha}^{-1} \mathrm{~N}, \mathrm{P}_{2} \mathrm{O}_{5}, \mathrm{~K}_{2} \mathrm{O}\left(\mathrm{T}_{1}\right)$ produced significantly higher grain yield (5.98 $\mathrm{t} \mathrm{ha}^{-1}$ ) but comparable to those applied with 60-30-30 kg $\mathrm{ha}^{-1} \mathrm{~N}, \mathrm{P}_{2} \mathrm{O}_{5}, \mathrm{~K}_{2} \mathrm{O}$ combined with $5 \mathrm{t} \mathrm{ha}^{-1}$ OF Plus (5.55 $\mathrm{t}$ ha ${ }^{-1}$ ). On the other hand, plants applied with 60-30-30 kg ha ${ }^{-1} \mathrm{~N}_{2} \mathrm{P}_{2} \mathrm{O}_{5}, \mathrm{~K}_{2} \mathrm{O}$ inorganic fertilizer combined with $2.5 \mathrm{t} \mathrm{ha}^{-1} \mathrm{OF}$ Plus $\left(\mathrm{T}_{4}\right)$ gave comparable grain yield with those which received 5 tha ${ }^{-1} \mathrm{OF}$ Plus $\left(\mathrm{T}_{3}\right)$. The unfertilized plants produced the lowest grain yield of 3.36 tha $^{-1}$.

In terms of harvest index (HI), plants applied with $120-60-60 \mathrm{~kg} \mathrm{ha}^{-1} \mathrm{~N}$, $\mathrm{P}_{2} \mathrm{O}_{5}, \mathrm{~K}_{2} \mathrm{O}$ inorganic fertilizer $\left(\mathrm{T}_{1}\right)$ had the highest $\mathrm{HI}$ value. This was followed by 60-30-30 $+5 \mathrm{t} \mathrm{ha}^{-1}$ OF Plus. Plants applied with pure organic fertilizer at 10 t ha $^{-1}$ OF Plus $\left(\mathrm{T}_{2}\right)$ had HI values comparable to those applied 
with 60-30-30 kg ha ${ }^{-1} \mathrm{~N}, \mathrm{P}_{2} \mathrm{O}_{5}, \mathrm{~K}_{2} \mathrm{O}+2.5 \mathrm{t} \mathrm{ha}^{-1}$ OF Plus $\left(\mathrm{T}_{4}\right)$ and the unfertilized control $\left(\mathrm{T}_{0}\right)$. The result suggests that the readily available macro nutrients (NPK) provided by the inorganic fertilizer enhanced the growth and development of rice plants that lead to the production of more productive tillers, longer panicle, more filled grains, heavier grains and consequently higher grain yield. This result suggests that there was more translocation of photosynthates or assimilates to the grains than to the straw as shown by higher HI. This further suggests that plants not applied with fertilizer had restricted growth and development of tillers, leaves, panicles and grains resulting in limited photosynthetic source-sink relation.

However, for the combined application of organic and inorganic fertilizers $\left(\mathrm{T}_{3}\right)$ and $\left(\mathrm{T}_{4}\right)$, the significant effects were due to the adequate supply of nutrient elements (NPK) provided by the applied inorganic fertilizer and nutrients from the organic fertilizer. This result corroborates the findings of Baltonado (1972) that rice plants applied with high levels of $\mathrm{N}$ fertilizer grew taller, developed darker green leaves and had more vigorous appearance than the unfertilized plants.

\section{Cost and Return Analysis}

Table 8 shows that inbred rice NSIC Rc212 obtained higher gross income of $\mathrm{PhP} 88,308.00$ and net income of $\mathrm{PhP} 34,644.75$ than hybrid rice TH82 which had a gross and net income of PhP 88,200.00 and PhP $30,663.95$, respectively.

Different fertilizer applications markedly influenced the grain yield of both hybrid (TH82) and inbred (NSIC Rc212) rice thus, they differed in gross income and net income. Highest gross income of PhP 107,640.00 was obtained with plants applied with 120-60-60 kg ha ${ }^{-1} \mathrm{~N}, \mathrm{P}_{2} \mathrm{O}_{5}, \mathrm{~K}_{2} \mathrm{O}$. However, highest cost of production of $\mathrm{PhP} 88,643.00$ was incurred for plants applied with $10 \mathrm{t} \mathrm{ha}^{-1}$ OF Plus $\left(\mathrm{T}_{2}\right)$ due to the high cost of using the said organic fertilizer material.

Highest net income of $\mathrm{PhP} 63,212.75$ per hectare was realized with the application of 120-60-60 kg ha ${ }^{-1} \mathrm{~N}, \mathrm{P}_{2} \mathrm{O}_{5}, \mathrm{~K}_{2} \mathrm{O}$ due to higher grain yield obtained. This was followed by plants applied with $60-30-30 \mathrm{~kg} \mathrm{ha}^{-1} \mathrm{~N}, \mathrm{P}_{2} \mathrm{O}_{5}$, $\mathrm{K}_{2} \mathrm{O}$ combined with OF Plus at $2.5 \mathrm{t} \mathrm{ha}^{-1}$ with $\mathrm{PhP} 43,857.00$. On the other hand, a net loss of $\mathrm{PhP} 10,883.00$ was obtained in plants applied with pure $10 \mathrm{t} \mathrm{ha}^{-1}$ OF Plus $\left(\mathrm{T}_{2}\right)$. The loss in $\mathrm{T}_{2}$ was mainly attributed to the considerable high amount $(10 \mathrm{t})$ and expenses incurred in the procurement of organic fertilizer material. Baclayon (2013) reported a net loss in lowland rice production with the application of $15 \mathrm{t} \mathrm{ha}^{-1}$ organic fertilizer due to the higher cost of inputs. 
Table 8. Production cost and return analysis per hectare of lowland rice (Oryza sativa L.) as influenced by different varieties and combined application of organic and inorganic fertilizers

\begin{tabular}{|c|c|c|c|c|}
\hline Treatment & $\begin{array}{r}\text { Grain Yield } \\
(\mathrm{t} \mathrm{ha-1})\end{array}$ & $\begin{array}{l}\text { Gross Income } \\
\text { (PhP) }\end{array}$ & $\begin{array}{l}\text { Production } \\
\text { Cost } \\
\text { (PhP) }\end{array}$ & $\begin{array}{l}\text { Net Income } \\
\quad(P h P)\end{array}$ \\
\hline \multicolumn{5}{|l|}{ Varieties } \\
\hline$\overline{\text { Hybrid (TH82) }}$ & 4.90 & $88,200.00$ & $57,500.05$ & $30,663.95$ \\
\hline Inbred (NSIC Rc212) & 4.91 & $88,380.00$ & $53,663.25$ & $34,644.75$ \\
\hline \multicolumn{5}{|l|}{ Fertilizer Application } \\
\hline$\overline{T_{0}-\text { No fertilizer application (control) }}$ & $3.36 d$ & $60,480.00$ & $25,915.00$ & $34,565.00$ \\
\hline $\mathrm{T}_{1}-120-60-60 \mathrm{~kg} \mathrm{ha}^{-1} \mathrm{~N}, \mathrm{P}_{2} \mathrm{O}_{5}, \mathrm{~K}_{2} \mathrm{O}$ & 5.98 a & $107,640.00$ & $44,427.25$ & $63,212.75$ \\
\hline $\mathrm{T}_{2}-10 \mathrm{t} \mathrm{ha-1}$ OF Plus & $4.32 \mathrm{c}$ & $77,760.00$ & $88,643.00$ & $-10,883.00$ \\
\hline $\begin{array}{l}\mathrm{T}_{3}-60-30-30 \mathrm{~kg} \mathrm{ha}^{-1} \mathrm{~N}, \mathrm{P}_{2} \mathrm{O}_{5}, \mathrm{~K}_{2} \mathrm{O}+5 \mathrm{tha}^{-} \\
{ }^{1} \text { OF Plus }\end{array}$ & $5.55 a b$ & $99,900.00$ & $67,380.00$ & $32,520.00$ \\
\hline $\begin{array}{l}\mathrm{T}_{4}-60-30-30 \mathrm{~kg} \mathrm{ha}^{-1} \mathrm{~N}, \mathrm{P}_{2} \mathrm{O}_{5}, \mathrm{~K}_{2} \mathrm{O}+2.5 \mathrm{t} \\
\text { ha-1 }^{-1} \text { OF Plus }\end{array}$ & $5.30 \mathrm{~b}$ & $95,400.00$ & $51,543.00$ & $43,857.00$ \\
\hline
\end{tabular}

*Based on the current price of dry palay at $\mathrm{PhP} 18 \mathrm{~kg}^{-1}$

\section{CONCLUSIONS AND RECOMMENDATIONS}

Based on the results obtained, the following conclusions were drawn:

1. Regardless of fertilizer treatments, hybrid TH82 headed significantly earlier with markedly heavier shoot dry weight, more filled grains but with lower seed weight than inbred rice NSIC Rc212.

2. Application of inorganic fertilizer at the rate of $120-60-60 \mathrm{~kg} \mathrm{ha}^{-1} \mathrm{~N}$, $\mathrm{P}_{2} \mathrm{O}_{5}, \mathrm{~K}_{2} \mathrm{O}$ significantly increased plant height, produced larger leaf area index and higher straw yield and consequently higher grain yield.

3. The use of $2.5-5 \mathrm{t} \mathrm{ha}^{-1}$ OF Plus organic fertilizer combined with $50 \%$ inorganic fertilizer produced comparable panicle length, productive tillers, number of filled grains and weight of 1,000 grains with those applied with pure inorganic fertilizer at the rate of $120-60-60 \mathrm{~kg} \mathrm{ha}^{-1} \mathrm{~N}$, $\mathrm{P}_{2} \mathrm{O}_{5}, \mathrm{~K}_{2} \mathrm{O}$.

4. Plants applied with $5 \mathrm{tha}^{-1} \mathrm{OF}$ Pluscombined with $60-30-30 \mathrm{~kg} \mathrm{ha}^{-1} \mathrm{~N}, \mathrm{P}$ ${ }_{2} \mathrm{O}_{5}, \mathrm{~K}_{2} \mathrm{O}$ gave comparable root shoot ratio with those applied with 120-60-60 kg ha ${ }^{-1} \mathrm{~N}, \mathrm{P}_{2} \mathrm{O}_{5}, \mathrm{~K}_{2} \mathrm{O}$.

We recommend the application of inorganic fertilizer at the rate of 120 60-60 kg ha ${ }^{-1} \mathrm{~N}, \mathrm{P}_{2} \mathrm{O}_{5}, \mathrm{~K}_{2} \mathrm{O}$ regardless of rice varieties in areas with comparable agro-climatic conditions as VSU. The combined application of inorganic and organic fertilizers at the rate of 60-30-30 kg ha- ${ }^{-1}, \mathrm{P}_{2} \mathrm{O}_{5}, \mathrm{~K}_{2} \mathrm{O}+$ $2.5 \mathrm{t} \mathrm{ha}^{-1} \mathrm{OF}$ Plus organic fertilizer should be tested on other hybrid and inbred lowland rice varieties of different agro climatic conditions. 


\section{ACKNOWLEDGMENT}

The authors wish to thank the Department of Science and Technology (DOST) for the ASTHRDP-NSC scholarship. We also thank Dr. Victor B. Asio for his support which contributed to the realization of this endeavor.

\section{REFERENCES}

BACLAYON, A. I. 2013. Agronomic performance of lowland rice grown at different spacing and organic fertilizer levels under unflooded water management system during vegetative stage. Masters Thesis. VSU, Baybay City, Leyte.105 pp.

BALTONADO, R. F. 1972. The effect of different levels of nitrogen fertilizer on the growth and yield of IR 22 (Dry Season). Undergraduate Thesis. Visayas Agriculture College, Baybay, Leyte. $67 \mathrm{pp}$.

BAÑOC, D. M. 2000. Plastic response of crop root system under soil moisture stress conditions. Ph.D. Dissertation, Nagoya University, Japan.

BIDWELL, R. G. S. 1974. Plant Physiology: McMillan Publ. Co. Inc. 866 Third Ave., New York, New York. 10022. 643 pp.

CHANG, T. T. and B. S.VERGARA. 1972. Varietal diversity and morphoagronomic characteristics of upland rice. 72-90. In Major Research in Upland Rice. IRRI, Los Baños, Laguna. 255 pp.

FAO (FOOD AND AGRICULTURE ORGANIZATION). 2003. Organic matter. http://www.fao.org/ag/ca/doc/Organic-matter.pdf. Date accessed: December 2015.

FAGERIA, N. K. 2007. Yield Physiology of Rice. National Rice and Bean Research Center of Embrapa, Santo Antonio de Goaias, Go, Brazil. Journal of Plant Nutrition. 30: 843-879.

GOMEZ, K. A. 1972. Techniques for field experiments with rice. International Rice Research Institute, P. O. Box 933, Manila, Philippines. $46 \mathrm{p}$.

LANDON, J. R. 1991. Booker Tropical Soil Manual. A handbook for soil survey and Agricultural Land Evaluation in the Tropics and Sub tropics. Long Scientific and Technical John Wiley and Sons, Inc. New York, $474 \mathrm{pp}$.

MOHAMMAD, S. I. 2010. Effect of integrated nutrient management on yield and nutrient use efficiency of rice-rice cropping system. Ph.D. Thesis. BangandhuskeikhMujiburRahaman Agricultural University, Gsipur. 108 pp.

PALM, C. A., R. J. K. MYERS and S. M. NANDWA. 1997. Combined Use of Organic and Inorganic Nutrient Sources for Soil Fertility Maintenance and Replenishment in Replenishing Soil Fertility in Africa. 98 pp.

PATOLILIC, R. G. 1988. Growth and yield of upland rice as affected by different methods of planting and levels of nitrogen fertilizer. Undergraduate Thesis. Leyte State University, Visca, Baybay City, Leyte. 72 pp. 
VERGARA, B. S. 1992. Transplanting of Rice. Rev. Ed. Farmers Primer in Growing Rice. $92 \mathrm{pp}$.

YOSHIDA 1981

ZAMORA, R. F. 2007. Fertilizer and water management for lowland rice production.Undergraduate Thesis. VISCA, Baybay, Leyte. 51 pp. 